Beata Świecka*

\title{
WYKORZYSTANIE DETALICZNEJ BANKOWOŚCI ELEKTRONICZNEJ W ZARZĄDZANIU FINANSAMI OSOBISTYMI
}

\section{Wprowadzenie}

Zmiany, jakie nastąpiły w sektorze bankowości detalicznej w Polsce po 1989 r. są ogromne. Nastąpiło przejście od statusu nieznaczącego sektora do sektora będącego motorem rozwoju całego systemu bankowego w Polsce. Starając się sprostać potrzebom i oczekiwaniom potencjalnych klientów, banki zwiększają i udoskonalają wachlarz świadczonych przez siebie usług, czego przejawem jest elektronizacja działalności bankowej. Na zmianę kształtu sektora bankowości detalicznej miało wpływ to, jak zmienili się jego klienci, niewątpliwie w stopniu znacznie mniejszym niż banki, ale jednak o pewnym wpływie możemy mówić. To zainteresowanie bankowością elektroniczną, w szczególności najpierw kartami płatniczymi, potem bankowością internetową, a dzisiaj również i mobilną, wpłynęło na wysoki udział bankowości detalicznej w rynku. Technologie informacyjne są istotnym elementem w jej rozwoju, a w szczególności Internet, którego upowszechnienie pod koniec lat 90. XX w. stanowiło pewien przełom w rozwoju bankowości detalicznej. Nie można sobie już dziś wyobrazić bankowości bez elektronicznych mediów. Jest to forma już wpisana $w$ rynek, jeden $z$ najważniejszych elementów sprawczych zmian na rynku usług finansowych, prowadzących do radykalnej przemiany sposobu funkcjonowania banków, ich podejściu do klienta, zakresu i metody świadczonych usług. Celem niniejszego opracowania jest analiza i ocena znaczenia bankowości elektronicznej w zarządzaniu finansami osobistymi (ZFO). W opracowaniu wykorzystano głównie teoretyczne i empiryczne aspekty badanego zakresu. Na potrzeby pracy wykorzystano następującą hipotezę: Detaliczna bankowość elektroniczna oferuje narzędzia wspomagające zarządzanie finansami osobistymi, usprawniając tym samym cały proces

* Uniwersytet Szczeciński, Wydział Zarządzania i Ekonomiki Usług. 
zarządzania, jednakże niezbędnym elementem w tym procesie jest wiedza finansowa, która nada kierunek działaniom w zakresie zarządzania finansami.

\section{Zarządzanie finansami osobistymi}

Zarządzanie finansami osobistymi (ZFO) jest przedmiotem nauki, jak i praktyki życia gospodarczego. Teoria ZFO odnosi się do badania procesu i części składowych zarządzania w zakresie finansów osób indywidualnych oraz członków ich gospodarstw domowych, zaś praktyka dotyczy decyzji podejmowanych dla pozyskiwania dochodów, zakupu aktywów i sposobów ich sfinansowania. ZFO jest częścią finansów osobistych, które są nauką o osobistych i rodzinnych finansach uważanych za istotne w osiąganiu sukcesu finansowego. Dotyczą one oszczędzania, wydawania, zabezpieczenia i inwestowania własnych zasobów finansowych ${ }^{1}$. J.R. Kapoor twierdzi, iż ZFO jest procesem ciągłego gospodarowania pieniędzmi, składającym się z czynności związanych z przygotowaniem i realizacją operacji pieniężnych ${ }^{2}$. ZFO jest ciągiem decyzji i konkretnych działań, a ich efekt zależy od wiedzy, założonego celu, jak i determinacji oraz konsekwencji w działaniu, a także narzędzi wspomagających ten ciąg decyzyjny. Jest procesem polegającym $z$ jednej strony na powiększaniu dochodów, z drugiej strony odpowiednim ich wydatkowaniu w celu zwiększenia zamożności gospodarstwa domowego i poziomu życia. W procesie zarządzania finansami można wyróżnić wiele obszarów działania, z czego do głównych zaliczyć można: pozyskiwanie dochodów, wydatkowanie, zadłużanie, oszczędności i inwestycje, działalność w zakresie ubezpieczeń, planowanie emerytalne, zarządzanie w zakresie podatków. K. Jajuga zakreśla te obszary znacznie szerzej, wyróżniając: zarządzanie płynnością w odniesieniu do krótkoterminowych decyzji finansowych, w tym inwestycyjnych, długoterminowe decyzje finansowe odnoszące się do kredytów mieszkaniowych i hipotecznych oraz długoterminowych kredytów konsumpcyjnych; długoterminowe decyzje inwestycyjne, czyli klasyczne indywidualne inwestycje finansowe (akcje, obligacje, fundusze inwestycyjne) oraz nieklasyczne inwestycje (nieruchomości, dzieła sztuki, instrumenty pochodne), decyzje w zakresie zabezpieczenia kapitału, w tym ubezpieczenia na życie, ubezpieczenia zdrowotne, ubezpieczenia majątkowe i osobiste, a także decyzje emerytalne, $w$ tym decyzje dotyczące tworzenia kapitału emerytalnego oraz

\footnotetext{
1 E.T. Garman, R.E. Forgue, Personal finance, Cengage Learning, Canada 2014, s. 4.

2 J.R. Kapoor, L.R. Dlabay, H.R. Hughes, Personal finance, McGraw-Hill, New York 2007, s. 4.
} 
transferu majątku do najbliższej rodziny poprzez darowizny ${ }^{3}$. Wszystkie te obszary łączy wspólny mianownik, jakim jest planowanie finansowe, które wydaje się niedocenianym, ale bardzo istotnym obszarem sfery finansowej. Planowanie jest procesem projektowania pożądanego obrazu przyszłości oraz wskazaniem metod i kierunków jego najefektywniejszego osiągnięcia. Jest to więc proces ciągłego zadawania pytań dotyczących przewidywania stanu finansów w przyszłości. Planowanie jest procesem, który obejmuje kilka etapów działań, jak m.in. zbieranie informacji, ustalanie celów, identyfikacja problemów finansowych, przygotowanie alternatywnych rozwiązań, implementacja decyzji wybranych spośród dostępnych wariantów oraz powtórne sprawdzenie planu ${ }^{4}$. K. Jajuga definiuje osobiste planowanie finansowe jako proces planowania wydatków konsumpcyjnych, inwestycji i pozyskiwania środków finansowania w celu optymalizacji finansowej osoby fizycznej lub gospodarstwa domowego ${ }^{5}$. Planowanie na ogół koncentruje się wokół ustanawiania celów i decydowania o właściwym toku działań poprzez ustalanie zadań. $\mathrm{O}$ ile w przedsiębiorstwach jest to widoczne, to w gospodarstwach domowych wyznaczanie celu i kierunków działania jest często wątpliwe. W zasadzie najczęściej są to cele krótkoterminowe, nieprzekraczające roku. Poparciem tej tezy są m.in. badania Fundacji Kronenberga, z których wynika, iż najczęściej planujemy swoje wydatki najdłużej do roku, co świadczy o wykorzystywaniu wyłącznie krótkookresowej perspektywy czasowej i braku realizacji działań w perspektywie średnio- i długoterminowej. Polacy większe wydatki najczęściej planują z miesięcznym lub półrocznym wyprzedzeniem. Co ciekawe, duże zakupy na sześć miesięcy przed najchętniej planują osoby o najwyższym dochodzie na osobę w gospodarstwie - powyżej 2001 PLN miesięcznie (36\%). Z kolei miesiąc wcześniej o poważnych wydatkach najczęściej myślą gospodarstwa posiadające dochód na osobę od 1001 do 1500 PLN (50\%). Duże znaczenie w planowaniu wydatków odgrywa wiek. Osoby w średnim wieku i starsze podejmują odpowiednie kroki nieco wcześniej niż osoby młode, które planują na ostatnią chwilę albo nie planują w ogóle. W grupie osób, które planują na tydzień przed większym wydatkiem znajdują się głównie Polacy, których stać na to, aby od razu wyłożyć odpowiednią kwotę pieniędzy ${ }^{6}$.

3 K. Jajuga, Nowe tendencje w zarządzaniu finansami osób indywidualnych $\mathrm{w}$ : Rynek finansowy. Inspiracje $z$ integracji europejskiej, red. P. Karpuś, J. Węcławski, Wydawnictwo UMCS, Lublin 2008, s. 124-130.

4 D. Harrison, Personal financial planning. Theory and practice, Pearson Education, Edinburgh 2005, s. 4.

5 K. Jajuga, Inwestycje w osobistym planowaniu finansowym w: K. Jajuga, J. Jajuga, Inwestycje. Instrumenty finansowe. Aktywa niefinansowe. Ryzyko finansowe. Inżynieria finansowa, PWN, Warszawa 2008, s. 390.

6 Badanie mające na celu poznanie postaw Polaków względem finansów osobistych, m.in. planowania i kontrolowania budżetu domowego, oszczędzania, inwestowania oraz korzystania z szybkich kredytów gotówkowych, termin realizacji wrzesień 2014; reprezentatywna ogólnopolska próba mieszkańców Polski w wieku 15 i więcej lat, $\mathrm{n}=1000$, Postawy Polaków wobec oszczędzania, Raport Fundacji Kronenberga przy Citi Handlowy, PBS, październik 2014, s. 23. 
Planowanie finansowe lub też planowanie własnych finansów powinno być procesem ciągłym, który pozwala na realizację określonego celu poprzez usystematyzowanie działań, ocenę sytuacji finansowej i harmonogramu działań. Planowanie to określanie pożądanego przyszłego stanu i czasu jego osiągnięcia oraz ustalenie działań niezbędnych do osiągnięcia zamierzeń mających formę planu, które nie mogłyby się urzeczywistnić naturalną koleją rzeczy.

Należy wziąć pod uwagę, że nie każde zarządzanie finansowe jest efektywne i skuteczne. Przez efektywne zarządzanie finansami osobistymi rozumie się proces polegający na zwiększaniu środków finansowych, przy jednoczesnym utrzymaniu takiego poziomu kosztów, który prowadzi do zwiększenia zamożności i poziomu życia gospodarstwa domowego. Ponadto uważam za zasadne odniesienie do świadomości finansowej, używając pojęcia świadomego zarządzania finansami osobistymi, przez które rozumiem konsekwentną pracę od podstaw, systematyczne działanie mające na celu doskonalenie poprzez ustalenie właściwej struktury dochodów i wydatków. To niewątpliwie proces, który może w perspektywie długoterminowej dać szansę poprawy skuteczności angażowania środków finansowych i jednostek czasu.

Zarządzanie finansami osobistymi jest ciągiem decyzji finansowych. Jedną z decyzji finansowych jest konsumpcja, inną zadłużenie, jeszcze inną oszczędności i inwestycje. Konsekwencją podejmowanych decyzji finansowych w zakresie zarządzania finansami osobistymi jest dobra lub zła sytuacja (kondycja) finansowa osoby fizycznej, która nie tylko zależy od wysokości dochodów, ale od niewydatkowania na dobra. Często członkowie gospodarstw domowych mówią "gdybym więcej zarabiał...., mając wyobrażenie, iż wysokość dochodów jest bezpośrednio skorelowana z zamożnością. Faktem jest, że większy dochód związany jest z wyższym poziomem życia, a tym samym i jego jakością, jednakże nie zawsze to oznacza zwiększoną zamożność. Generalnie można wyróżnić kilka strategii zarządzania finansami osobistymi, jedną z nich jest wzrost dochodów, drugą obniżka kosztów, należy przy tym nadmienić, że wzrost dochodów bez jednoczesnej zmiany starych, nieefektywnych nawyków, nie zmieni nic prócz zwiększenia wydatków na bieżącą konsumpcję, nie zwiększając przy tym środków na przyszłą konsumpcję. Dlatego też mówiąc o efektywnym zarządzaniu finansami osobistymi należy podkreślić, iż jest to świadome, zaplanowane wcześniej działanie w sferze finansów, pozwalające na realizację działań krok po kroku według wcześniej założonego celu i planu działania, poprzez określenie stanu wyjściowego sytuacji finansowej, tworzenie planu finansowego przy jednoczesnym ustaleniu celowości działania oraz określeniu obszaru działań i wielkości środków, jakie mają być na te działania przeznaczone, w tym na: bieżącą konsumpcję, oszczędności, inwestycję, edukację, rozrywkę, nieprzewidziane wydatki czy działania charytatywne. Niezbędne przy tym są również kontrola założonego 
planu i ewentualna korekta działań pozwalające dokładniej zrealizować założone wcześniej cele finansowe.

Efektywne zarządzanie finansami osobistymi zależy od wiedzy, jak i narzędzi wspomagających proces $\mathrm{ZFO}^{7}$. Wiedza finansowa została zdefiniowana przez M. Noctor, S. Stoney i R. Stradlin jako zdolność do świadomych osądów i podejmowania skutecznych decyzji dotyczących wykorzystania i zarządzania pieniędzmi. Według S.J. Huston wiedza finansowa (financial literacy, financial knowledge) ma dwa wymiary: zrozumienie informacji finansowych oraz aplikację, zastosowanie w praktyce życia codziennego ${ }^{8}$. Wiedza może być efektem edukacji formalnej zdobytej w szkołach (o którą dość trudno), jak również nieformalnej, profesjonalnej, zdobytej po zakończeniu edukacji formalnej w postaci kursów, szkoleń. Zdobyta wiedza w zakresie finansów osobistych nie tylko umożliwia bardziej efektywne zarządzanie nimi, ale również warunkuje pełne uczestnictwo w życiu gospodarczym i zwiększenie ubankowienia społeczeństwa, a tym samym korzystanie z coraz to bardziej wyrafinowanych produktów bankowych oraz nowoczesnych narzędzi oferowanych przez bankowość elektroniczną. Wiele krajów zdecydowało się na wdrożenie narodowych programów edukacji finansowej, m.in. Wielka Brytania, Japonia, Stany Zjednoczone. W Polsce edukacja finansowa wprowadzona jest w okrojonym zakresie. Od lat Narodowy Bank Polski, a także Fundacja Kronenbega i inne instytucje tworzone przy bankach wspierają edukację finansową, jednakże wydaje się, że jest to kropla w morzu potrzeb. Niezbędna jest spójna, długofalowa strategia, która może dać efekty w skutecznym i bardziej efektywnym zarządzaniu finansami w okresie długoterminowym. Uzupełnieniem wiedzy są narzędzia, m.in. bankowość elektroniczna, która od dobrych kilku lat oferuje aplikacje w ramach bankowości internetowej, a także mobilnej, co szerzej zostało przedstawione w kolejnym punkcie opracowania.

\section{Detaliczna bankowość elektroniczna - pojęcie, klasyfikacja, klienci}

Detaliczna bankowość elektroniczna umożliwia klientowi indywidualnemu dostęp do rachunku bankowego poprzez elektroniczne kanały dystrybucji, jak również

7 M. Noctor, S. Stoney, R. Stradlin, Financial literacy: A discussion of concepts and competences of financial literacy and opportunities for its introduction into young people's learning. Report National Westminster Bank, National Foundation for Education Research, London 1992, w: D.J. Beal, S.B. Delpachitra, Financial literacy among Australian university students, "Economic Paper" 2003, Vol. 22, No. 1, s. 65-78.

8 S.J. Huston, Measuring financial literacy, "Journal of Consumer Affairs" 2010, Vol. 44, No. 2, s. 296-316. 
realizację płatności przy wykorzystaniu elektronicznych instrumentów płatniczych oraz mobilnych urządzeń. Jest formą kontaktu klienta z bankiem, przy wykorzystaniu takich urządzeń jak m.in: komputery, telefony, elektroniczne instrumenty płatnicze i bankomaty, elektroniczne terminale do akceptowania kart płatniczych czy też kioski multimedialne. Mając na uwadze fakt, iż pojęcie bankowości elektronicznej jest bardzo szerokie i zawiera w sobie zarówno bankowość internetową, mobilną, terminalową, modemową oraz elektroniczne instrumenty płatnicze, zapewnia ona wielokanałowy dostęp klienta do banku. Rodzi się jednak pytanie, czy bankowość elektroniczna jest dobrym narzędziem wspomagającym zarządzanie finansami osobistymi?

Rysunek 1. Wielokanałowość w detalicznej bankowości elektronicznej

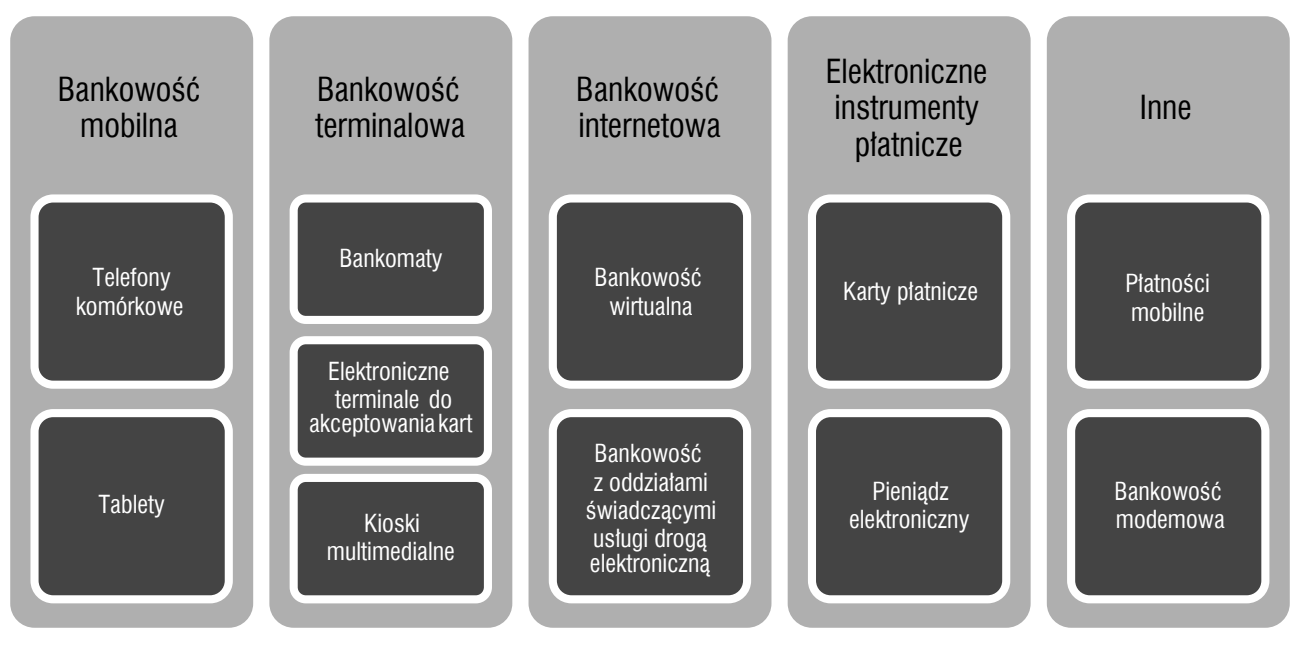

Źródło: Opracowanie własne.

Na detaliczną bankowość elektroniczną można spojrzeć z kilku punktów widzenia, jednakże na potrzeby tego opracowania przytoczono dwa podejścia: $z$ punktu widzenia klientów i form komunikacji klienta z bankiem. Odnośnie do pierwszego podejścia $\mathrm{z}$ punktu widzenia zarządzania finansami osobistymi ważni są klienci aktywni, korzystający z licznych produktów i usług bankowych w przeciwieństwie do pasywnych, którzy w skrajnych wypadkach, posiadając rachunek osobisty, na który wpływa wynagrodzenie z tytułu pracy, raz w miesiącu udają się do bankomatu w celu wybrania wszystkich środków z konta. Klienci aktywni poszukują nowych rozwiązań, korzystają $z$ aplikacji mobilnych, są otwarci na nowe propozycje, szybko akceptują nowości. Wśród aktywnych są również tzw. naśladowcy, akceptujący np. płatności zbliżeniowe, mobilne, jednakże potrzebujący więcej czasu na reakcję i korzystający z instrumentów bankowości elektronicznej, gdy są już one sprawdzone. Najtrudniej jest z grupą 
tzw. konserwatystów, przywiązanych do tradycyjnych produktów i form świadczenia usług bankowych, niechętnych do korzystania z elektronicznych kanałów dystrybucji, nowych aplikacji do zarządzania finansami osobistymi, dla których Excel i przysłowiowa świnka skarbonka są właściwymi narzędziami. Są też klienci poszukujący bezpieczeństwa, u których elektroniczne aplikacje do zarządzania finansami osobistymi nie są na liście priorytetów. To typowi indywidualiści, dla których najważniejsze jest bezpieczeństwo, korzystający najczęściej ze sprawdzonych usług bankowych. Są też klienci mobilni, z reguły mający wysokie dochody i wyższy status społeczny, chętnie korzystający z nowości, zaciągający kredyty i realizujący operacje bankowe przy wykorzystaniu elektronicznych kanałów dystrybucji usług bankowych i bankowości mobilnej. Tradycjonaliści wykorzystują podstawowe usługi z zakresu oferty bankowej, najczęściej poprzez sprawdzone kanały dystrybucji, w tym w dużej mierze oddział bankowy.

Według form komunikacji detaliczną bankowość elektroniczną podzielić można na kilka segmentów: bankowość modemową, telefoniczną, terminalową, telewizyjną, internetową, a także elektroniczne instrumenty płatnicze. Formą detalicznej bankowości elektronicznej, która miała szczególne znaczenie i stała się punkiem zwrotnym w rozwoju bankowości elektronicznej stanowiły elektroniczne instrumenty płatnicze, w tym głównie karty płatnicze. To jedne z pierwszych narzędzi bankowości elektronicznej, która uzupełniona przez bankowość internetową pozwala klientowi na sprawną realizację usług bankowych, a obecnie w dużym zakresie racjonalizowanie wydatków, tworzenie budżetu, kategoryzację wydatków i dochodów, automatyczne oszczędzanie i wiele innych. W sektorze klientów detalicznych bankowość internetowa, pomimo późniejszego wejścia na rynek niż bankowość modemowa, zyskała znacznie większą liczbę klientów. Przyczyną tego zjawiska może być fakt, że w początkowym etapie rozwoju bankowość modemowa była adresowana wyłącznie dla klientów instytucjonalnych, dopiero z biegiem czasu i rozwoju elektronicznych instrumentów płatniczych została zaadresowana również do klienta indywidualnego. Uzupełnieniem tych dwóch form jest bankowość terminalowa, rozwijająca się równolegle $\mathrm{z}$ elektronicznymi instrumentami płatniczymi, jak również bankowość mobilna, która w ostatnim czasie zyskuje coraz większe znaczenie.

\section{Znaczenie bankowości elektronicznej w zarządzaniu finansami osobistymi}

Bankowość elektroniczna jest znaczącym narzędziem wykorzystywanym w zarządzaniu finansami osobistymi. Z badania Barometr Finansowy ING realizowanego 
w 10 krajach, w tym w Polsce, mierzącego poziom wiedzy finansowej konsumentów oraz jej wpływ na zachowania i postawy wobec zagadnień finansowych, wynika, iż 93\% Polaków chciałoby lepiej zarządzać swoimi finansami, 63\% Polaków ma podstawową wiedzę z zakresu finansów. Stawia to nasz kraj na 7. miejscu wśród 10 przebadanych krajów. Polacy nie poszerzają aktywnie swojej wiedzy finansowej - 36\% odkłada to na później (26\% we wszystkich krajach). Tłumaczy się to brakiem czasu (25\% Polaków, 20\% we wszystkich krajach), 46\% Polaków nie ma odłożonych żadnych środków na czarną godzinę (33\% na świecie) - gorzej wypadli tylko Amerykanie (48\%). W Polsce 61\% respondentów planuje swój budżet domowy (30\% ankietowanych globalnie), a spośród nich $37 \%$ planuje ten budżet na komputerze (44\% ankietowanych globalnie). Z Badania Finansowy Barometr ING. Międzynarodowe badanie na temat postaw i zachowań konsumentów wobec oszczędzania w Polsce i na świecie, wynika, iż Polacy są umiarkowanymi zwolennikami korzystania z kart kredytowych - co drugi mieszkaniec Polski woli korzystać z debetu na rachunku niż z karty kredytowej (50\%). Odstajemy jednak od europejskiej średniej pod względem skłonności do odkładania naszych zachcianek, gdy nie mamy na nie środków - 72\% Polaków woli ponosić opłaty za debet na rachunku niż wstrzymać się od zakupów (średnia 77\%). Sytuacja ekonomiczna blisko trzech czwartych Polaków poprawiła się lub nie zmieniła w ostatnim czasie (71\%). Pod tym względem Polska wypada korzystnie na tle Europy (średnia 63\%). Jednocześnie na pogorszenie się sytuacji wskazało 29\% mieszkańców Polski9.

Edukacja finansowa jest niezbędna, a przy tym ważna jest znajomość i korzystanie $\mathrm{z}$ instrumentów pomocnych $\mathrm{w}$ zarządzaniu finansami. $Z$ jednej strony pomocna jest obsługa podstawowych programów, w tym Excela, ale rynek oferuje bardziej zaawansowane, (nie znaczy trudne) narzędzia bankowości elektronicznej i nie tylko. Pomocne w tym zakresie są internetowe aplikacje wspomagające zarządzanie finansami osobistymi typu Personal Financial Management (PFM), będące narzędziem informatycznym, które służy do śledzenia i zarządzania osobistymi finansami. Często umożliwiają one agregowanie informacji finansowych pochodzących z różnych źródeł, pozwalają na zaimportowanie plików wyciągów z serwisów bankowości internetowej oraz automatyczne rozpoznanie kategorii, do której należy przypisać

\footnotetext{
9 Finansowy Barometr ING to cykliczne badanie realizowane dla Grupy ING przez grupę badawczą IPSOS. Badanie zostało zrealizowane w trzynastu krajach m.in. w Polsce, Niemczech, Wielkiej Brytanii, Francji, Hiszpanii, Holandii i Turcji. Ostatnia edycja badania została przeprowadzona w październiku i listopadzie 2014 r. Wzięło w niej udział ponad 12743 respondentów, w tym 1037 z Polski, Finansowy Barometr ING. Międzynarodowe badanie na temat postaw i zachowań konsumentów wobec oszczędzania w Polsce i na świecie, IPSOS, Warszawa marzec 2015.
} 
dochód czy wydatek ${ }^{10}$. PFM dostarcza użytkownikom informacji o stanie ich finansów, strukturze wydatków i przychodów, pomaga tworzyć budżety, planować finanse w krótkim i długim terminie, kategoryzuje wydatki. PFM początkowo miał formę aplikacji instalowanych na komputerze użytkownika, a informacje musiały być ręcznie wprowadzane do programu. Następnie aplikacje zostały wzbogacone o funkcję importowania historii rachunków bankowych poprzez plik wsadowy wygenerowany w systemie bankowości internetowej. Obecnie najpopularniejszą formą PFM są aplikacje webowe (czyli, upraszczając, serwisy internetowe - przede wszystkim dostarczane przez instytucje niefinansowe, ale także coraz częściej przez same banki jako oddzielny moduł w bankowości internetowej, a nawet mobilnej), spełniające następujące funkcje:

- PFM automatycznie kategoryzuje transakcje, dzięki czemu użytkownik (tak samo jak bank) poznaje strukturę swoich wydatków,

- system oblicza miesięczny budżet, łącząc zaplanowane i już zrealizowane przychody i wydatki, dzięki czemu użytkownik wie, jaką część dochodu może przeznaczyć na inwestycje,

- PFM pozwala zaplanować przyszłe wydatki, np. wyjazdy wakacyjne lub uroczystości rodzinne; na podstawie tej wiedzy łatwiej zadecydować np. o zaciągnięciu pożyczki na pokrycie brakujących środków, wysokości rat, itp.

Banki oferują pakiet innowacyjnych rozwiązań technologicznych, m.in. możliwość przelewów bez znajomości konta adresata - przy użyciu Facebooka, e-maila i SMS-a, płatności zbliżeniowe telefonem. MasterCard wprowadził kartę display, która dzięki wbudowanemu ekranowi i funkcji tokenu umożliwia kontrolę wydatków. Klienci bankowości elektronicznej mają możliwość wykorzystania narzędzi zarządzania finansami osobistymi i z aplikacji pomagających w oszczędzaniu. Zyskują możliwość generowania zestawień i statystyk związanych z przepływem środków. Atrakcyjnie zaprojektowany interface umożliwia w prosty i czytelny sposób definiowanie kategorii wydatków oraz ułatwia planowanie domowego budżetu. Dzięki nowoczesnym rozwiązaniom dostępnym w ramach bankowości internetowej, oszczędzanie jest proste i niekiedy intuicyjne. Istnieje możliwość specjalnego stworzenia celowych kont oszczędnościowych (CKO), które umożliwią odkładanie pieniędzy na wybrany cel.

Jedną z ciekawszych funkcjonalności powiązanych z płatnościami bezgotówkowymi są programy automatycznego oszczędzania. Taka metoda pozwala na automatyczne i systematyczne oszczędzanie znaczących kwot. Program automatycznego oszczędzania to usługa dla posiadaczy rachunku osobistego pozwalająca na gromadzenie

\footnotetext{
${ }^{10}$ Finanse osobiste. Zachowania - produkty - strategie, red. E. Bogacka-Kisiel, PWN, Warszawa 2012, s. 108 i nast.
} 
drobnych kwot przy okazji płatności kartą debetową, wypłat gotówki z bankomatów czy realizacji przelewów internetowych. Ta forma oszczędzania wykorzystująca elektroniczne media polega na zaokrąglaniu kwoty płatności kartą w górę (np. do pełnych 10 zł) i przelewaniu różnicy pomiędzy zaokrągloną kwotą a kwotą transakcji na specjalne konto oszczędnościowe, przelewaniu ustalonego procentu od kwoty transakcji kartą na dedykowane oprocentowane konto oszczędnościowe, pobieraniu stałej kwoty przy okazji każdej transakcji i przelewaniu jej na konto oszczędnościowe. Opłacalność zależy od tego, jak często dokonuje się płatności kartą i jakie zaokrąglenie klient wybierze lub jaką wysokość kwoty chce oszczędzić po dokonaniu transakcji kartą. Oszczędzanie automatyczne (nazywane oszczędzaniem mimochodem) to usługa, która ma przede wszystkim pozytywny wymiar finansowy dla osób mających problem z systematycznym odkładaniem pieniędzy. Do banków oferujących usługę automatycznego oszczędzania należą m.in: Credit Agricole - CA Saver, mBank - mSaver, ING Bank Śląski - Smart Saver, Getin Bank - Zachowaj Resztę oraz PKO BP - Autooszczędzanie.

Ciekawym rozwiązaniem dla klientów detalicznych jest oferowana przez mBank możliwość założenia kilku kont w celu realizacji „zasady sześciu kont”. Jest to zasada zarządzania finansami osobistymi polegająca na tym, iż klient zakładając te konta, dedykuje je do ściśle określonego celu umożliwiającego efektywniejsze gospodarowanie środkami finansowymi. Każde $\mathrm{z}$ nich ma swoje przeznaczenie:

- konto 1. - 55\% miesięcznego wynagrodzenia; środki te mają posłużyć na wydatki bieżące,

- konto 2-10\% miesięcznego wynagrodzenia; środki te mają posłużyć na edukację, która wbrew pozorom pozwala z miesiąca na miesiąc rozwijać swoje umiejętności finansowe,

- konto 3-10\% miesięcznego wynagrodzenia; środki te mają posłużyć na oszczędności i inwestycje. Jest to konto, z którego środków ruszyć nie można,

- konto 4-10\% miesięcznego wynagrodzenia; środki te mają posłużyć na nieprzewidziane wydatki, które zazwyczaj się zdarzają, jak awaria pralki itp.,

- konto 5-10\% miesięcznego wynagrodzenia; środki te mają posłużyć na rozrywkę, muszą być spożytkowane w trakcie miesiąca bieżącego, nie mogą być transferowane na kolejny miesiąc; ta konieczność wydatkowania w trakcie miesiąca bieżącego związana jest $\mathrm{z}$ faktem, iż stosowanie zasady sześciu kont jest pewnym wyrzeczeniem (związanym z przeznaczeniem nie $100 \%$, lecz tylko $55 \%$ na bieżącą konsumpcję) i zmianą starych nawyków, dlatego też niezbędna jest przyjemność, która złagodzi zmianę nawyków w zakresie zarządzania finansami osobistymi,

- konto 6-5\% miesięcznego wynagrodzenia; środki te mają posłużyć na wydatki na cele charytatywne. 
Pomocne w zarządzaniu finansami osobistymi są aplikacje mobilne oferowane na telefon komórkowy umożliwiające bieżący wgląd w sytuację finansową i transfer środków między kontami. Zastanowić się przy tym należy nad efektywnym wykorzystaniem kart płatniczych. $Z$ badań naukowych wynika, że płacący kartami wydają znacznie więcej niż gotówką, co burzy idylliczny obraz wykorzystania instrumentów $\mathrm{BE}$ do ZFO. Należy przy tym dodać, że pewnym aspektem negatywnym jest dostęp do pieniędzy, których klient nie posiada, czego obrazem są karty kredytowe, jak i karty obciążeniowe. W momencie realizacji transakcji gotówkowej w bankomacie klient, otrzymuje informację o braku środków na koncie, ale następnie o dostępności kredytu na koncie, który zaspokoi jego bieżącą potrzebę. Z punktu widzenia dostępności do pieniądza jest to niewątpliwie dobre, jednakże z punktu widzenia ZFO, niekoniecznie. Jest to zjawisko bardzo złożone, gdyż w grę wchodzą cechy osobowościowe i wspomniana wiedza finansowa wynikająca $z$ wcześniejszej edukacji finansowej.

\section{Podsumowanie}

Z punktu widzenia klienta detalicznego korzystnie z usług bankowości elektronicznej przynosi wymierne korzyści. Jedną z nich jest możliwość zarządzania finansami osobistymi. Dzięki upowszechnianiu narzędzi BE staje się możliwe zapewnienie elastyczności w zakresie korzystania z nowych usług i produktów, aplikacji umożliwiających efektywniejsze zarządzanie finansami osobistymi. Ułatwiają one obniżanie kosztów transakcji, a także podniesienie jakości obsługi usług. System bankowości elektronicznej, a zwłaszcza internetowej i mobilnej ma bogatą funkcjonalność, zapewniającą pełny i wygodny dostęp do własnych finansów, umożliwia przejrzysty system zarządzania środkami, dzięki któremu klient ma pełniejszy obraz własnej sytuacji finansowej. Pełen monitoring, przejrzystość cen, swoboda dotarcia do informacji, ukazującej zróżnicowanie cenowe, pełen wachlarz oferty produktowej banku, w którym klient posiada konto oraz banków konkurencyjnych pozwalają przy podstawowej wiedzy ekonomicznej na właściwe podejmowanie decyzji w zakresie zarządzania finansami osobistymi. Zapewniony szybki dostęp do usług finansowych pozwala zarówno zaoszczędzić czas, jak i zwiększa komfort dokonywanych operacji finansowych. Bankowość elektroniczna jest zestawem narzędzi wspierających zarządzanie finansami, jednakże oprócz narzędzi niezbędna jest wiedza finansowa, jak je wykorzystać. Innymi słowy narzędzia nie wystarczą, są pomocne, ale kluczowym elementem jest wiedza z zakresu efektywnego zarządzania finansami. Znajomość narzędzi bankowości elektronicznej nie odpowie na pytania: skąd wziąć środki 
na emeryturę? Jak zabezpieczyć finansowo siebie i swoją rodzinę? Czy kapitalizacja odsetek działa na moją korzyść? Jak zastosować dźwignię finansową przy zakupie mieszkania? Jaką strategię podatkową wykorzystać przy zakupie nieruchomości? Jak uzyskać niezależność finansową? Jakie ma znaczenie planowanie średnio- i długoterminowe? Do odpowiedzi na takie pytania potrzebna jest wiedza fachowa uzyskana na drodze edukacji formalnej jak i nieformalnej, jednakże bankowość elektroniczna jest dużym wsparciem w usprawnieniu procesu zarządzania własnymi pieniędzmi.

\section{Bibliografia}

Beal D.J., Delpachitra S.B., Financial literacy among Australian university students, "Economic Paper" Vol. 22, No. 1, March 2003.

Finanse osobiste, zachowania - produkty - strategie, red. E. Bogacka-Kisiel, PWN, Warszawa 2012.

Finansowy Barometr ING. Międzynarodowe badanie na temat postaw i zachowań konsumentów wobec oszczędzania w Polsce i na świecie, IPSOS, Warszawa marzec 2015.

Garman E.T., Forgue R.E., Personal finance, Cengage Learning, Canada 2014.

Harrison D., Personal financial planning. Theory and practice, Pearson Education, Edinburgh 2005.

Huston S.J., Measuring financial literacy, "Journal of Consumer Affairs" 2010, Vol. 44, No. 2.

Jajuga K., Nowe tendencje w zarządzaniu finansami osób indywidualnych, w: Rynek finansowy. Inspiracje z integracji europejskiej, red. P. Karpuś, J. Węcławski, Wydawnictwo UMCS, Lublin 2008.

Jajuga K., Inwestycje w osobistym planowaniu finansowym, w: K. Jajuga, J. Jajuga, Inwestycje. Instrumenty finansowe. Aktywa niefinansowe. Ryzyko finansowe. Inżynieria finansowa, PWN, Warszawa 2008.

Kapoor J.R., Dlabay L.R., Hughes H.R., Personal finance, McGraw-Hill, New York 2007.

Noctor M., Stoney S., Stradlin R., Financial literacy: A discussion of concepts and competences of financial literacy and opportunities for its introduction into young people's learning. Report National Westminster Bank, National Foundation for Education Research, London 1992.

Postawy Polaków wobec oszczędzania, raport Fundacji Kronenberga przy City Handlowy, PBS, Warszawa 2014. 


\section{Retail E-Banking in Personal Finances' Management}

The purpose of the study is to analyze and evaluate usage of electronic banking in personal finances' management. In the paper the following hypothesis is verified: Retail e-banking offers tools to help manage personal finances and thus facilitates the entire management process, however financial literacy is essential as it gives direction to the activities in the field of financial management.

Keywords: retail banking, personal finance management, households, financial literacy

\section{Les services bancaires électroniques de détail dans la gestion des finances personnelles}

Le but de l'étude est d'analyser et d'évaluer l'utilisation des services bancaires électroniques dans la gestion des finances personnelles. L'hypothèse suivante a été vérifiée: les services bancaires électroniques de détail offrent des outils pour aider à gérer les finances personnelles et donc ils facilitent le processus de la gestion, mais c'est la littératie financière qui est essentielle, car elle détermine la direction pour les activités dans le domaine de la gestion financière.

Mots-clés: la banque de détail, la gestion des finances personnelles, les ménages, la littératie financière

\section{Использование розничных банковских услуг в управлении личными финансами}

Цель статьи состоит в анализе и оценке использования электронного банкинга в управлении личными финансами. Исследование относится как к его теоретическому, так и к эмпирическому аспекту. В работе поставлена следующая гипотеза: Розничный банкинг предоставляет вспомогательные инструменты для управления личными финансами, облегчая весь процесс управления, которого существенным элементом является финансовая 
грамотность, определяющая направление деятельности в области финансового менеджмента.

Ключевые слова: розничный банкинг, управление личными финансами, домашние хозяйства, финансовая грамотность 